\title{
ALLELOPATHIC POTENTIAL OF CYPERUS ROTUNDUS L. AND CYNODAN DACTYLON L. ON GERMINATION AND GROWTH RESPONSES OF SOME RICE CULTIVARS
}

\author{
Kavitha, D*. \\ Department of Botany, Annamalai University, Annamalai Nagar-608 002-Tamil Nadu. \\ *E.mail: kavipriya2002@gmail.com
}

\begin{abstract}
Weeds are enemies to the crop plants and have harmful effects on agricultural crops due to several factors such as competition for space, light and nutrients and allelopathy. In the present study,various concentrations $(0,5,10,15,20$ and $25 \%)$ of whole plant aqueous extractsof weeds, Cyperus rotundusL. (Purple nut sedge) and Cynodan dactylon(L.) Pers. (Bermuda grass) were tested for assessing their allelopathic potential on seed germination and seedling growth of some rice (Oryza sativa L.) cultivars i.e.ADT-36,BPT5204 and IR-20 using pot culture experiments. The experimental results revealed that all the concentrations of both the weed extracts had inhibition on germination percentage, seedling length, number of,dry weight and chlorophyll contents of 15 day old seedlings of all the three rice cultivars and the inhibitory effect of the extracts was concentration dependent. However, at $5 \%$ of $C$. rotundus and $10 \%$ of $C$. dactylon extracts did not affect seed germination of IR-20. Among the rice cultivars,the higher degree of growth inhibition was observed in ADT-36followed by BPT-5204 and IR-20. The weed C.rotundusexhibited more intense on growth suppression of rice cultivars thanC.dactylon.
\end{abstract}

Keywords: Allelopathic potential, Cyperus rotundus, Cynodan dactylon, rice cultivars.

\section{INTRODUCTION}

Allelopathy is an important mechanism of plant interference by the addition of plant-produced phytotoxins to the plant environment. Many of the phytotoxic substances suspected of causing germination and growth inhibition have been identified from plant tissues and soil (Whittaker and Fenny, 1971). Allelopathy is of two types, one is true allelopathy and other is functional allelopathy. The true allelopathy is the release of substances that are toxic in the form in which they are produced in the plant. Functional allelopathy is the release of substances that are toxic or a result of transformation by micro-organism (Wittekar, 1999). According to Muller (1969) the term allelopathy refers to the overall influence of one plant on another, due to the chemical compounds being added to the environment. The phenomenon of allelopathy has reviewed a wide attention in the past three decades in India. Of the total annual loss of agricultural produce due to various pests in India, weeds account for $45 \%$, insects $30 \%$, diseases $20 \%$ and other pests, 5\% (Rao, 1983). In crops field, weeds and crops mutually infer of each other, which may reduce the growth of one or both species.

Allelopathy can be the most effective form of interference during the juvenile stages of the susceptible plants and allelopathic interactions play a major role in the determining the distributions of plants in nature and yield of different crops(Fisher, 1980).Hence, in the present investigation an attempt has been made to study the allelopathic effect of Cyperusrotundus L. and Cynodan dactylon L. on seed germination and seedling growth of some rice (Oryza sativa L.) cultivars ie.ADT-36,BPT-5204 and IR-20.

\section{MATERIALS AND METHODS}

The preparation of aqueous weed extracts and germination studies were followed as per the methods of Padhy et al. (2000) and Bhatt and Chauhan (2000).The collected fully matured whole parts of Cyperus rotundus L. and Cynodan dactylon L. were air dried, ground to fine powder and extracted in water. Twenty grams of ground weed material was soaked in one liter of distilled water and kept 48 hours at room temperature with occasional shaking. The infusion was decanted and filtered through three layers of Whatman No.1 filter paper. From this weed extracts (20\%) further dilutions of 15,10 and $5 \%$ were prepared with distilled water. The seeds of rice cultivars ie.ADT-36,BPT-5204 and IR-20were surface sterilized with $0.03 \%$ formalin solution for $20 \mathrm{~min}$. and then washed thoroughly with distilled water (DW). For the germination study 15 seeds were sown in earthen pots $(15 \mathrm{~cm} x$ $30 \mathrm{~cm}$ ) filled with $3.5 \mathrm{~kg}$ of normal garden soil. Equal quantity of weed extracts/DW was irrigated to all 
the pots on $0,3,6,9,12$ and 15 days after seed sown. Each treatment including control was replicated five times. The number of seeds germinated in each treatment was counted daily up to $7^{\text {th }}$ day after sowing, and germination percentage was calculated. The emergence of radicle was taken as criteria for germination. Five seedlings from each replicate was selected for recording the morphological parameters such as length of shoot and root, dry weight and chlorophyll contents on $15^{\text {th }}$ day after sowing. The mean data was statistically analysed by ANOVA followed by DMRT at $\mathrm{P}<0.5 \%$.

\section{RESULTS AND DISCUSSION}

Cyperus rotundus L. (family Cyperaceae), also known as purple nutsedge or nutgrass, is a common perennial weed with slender, scaly creeping rhizomes, bulbous at the base and arising singly from the tubers which are about 1-3 cm long. The tubers are externally blackish in colour and reddish white inside, with a characteristic odour. The stems grow to about $25 \mathrm{~cm}$ tall and the leaves are linear, dark green and grooved on the upper surface. Inflorescences are small, with 2-4 bracts, consisting of tiny flowers with a red-brown husk. The nut is three-angled, oblong-ovate, yellow in colour and black when ripe. C. rotundus is indigenous to India, but are now found in tropical, subtropical and temperate regions (Pooley,(1998); GordonGray,(1995)).

Cynodon dactylon (Family: Poaceae, Arugampullu in Tamil, Dhub in Hindi, Bermuda grass inEnglish). A creeping herb rooting at the joints withsmooth upward stem. The roots are whitish, tough andcreeping, almost woody with smooth fibers. Leavestapering to a sharp point, ribbed with smooth sheathand hairy stipules. Flowers are purplish arranged in twoclose alternative rows in equally crowed 4 or 5terminal, linear spikes and blooming in the mouth ofAugust to September (Nadkarni, 2000 and Vaidyaratnam, 2003).

Aqueous weed extracts of C.rotundusand $C$. dactyloncaused a significant inhibition on the germination of riceseeds over control. The intensity of inhibition differed depending upon the concentration, weed species and rice cultivars. As the concentration of the weed extracts increased the degree of inhibition on germination percentage was increasedin all the three rice cultivars (Table 1). The extracts of both the weed species significantly affected the germination percentage of rice cultivars more at their higher concentration (20\%) and the effect was more intense by the extracts of C.rotundus
thanC.dactylon. The reduction on the germination, seedling length and dry weight (Table 2) was observedmore in ADT-36 followed by BPT-5204 and IR-20. As the concentration increased, the seedling growth and dry weight of rice seedlings decreased. Similar results were obtained by Alsaadawi and Salih (2009), in which, they reported the root exudates of C. rotundus significantly reduced the root and shoot growth of tomato and cucumber plants. The result of Drost and Doll, (1980) favors the present findings, where the plant residues and tuber extracts of yellow nutsedge (Cyperus esculentus L.) inhibited the germination and growth of corn (Zea mays L.) and soybeans (Glycine max (L.) Merr.). Present results are also similar to the findings of Channappagoudaret al.,(2005),in which, they reported the extracts of Cyperus rotundus and Commelinabengalensishad an inhibitory effect on the germination, seedling length of wheat, green gram and soybean.Verma et al., (2002) found the extracts of Cyperus rotundus adversely inhibited the seed germination, seedling growth and biomass production of Brassica and tomato. Jeyasrinivaset al., (2006) reported the higher concentrations of leaf leachates of Trianthimumportulacastrum, Cyanodondoctylon and C.rotundus, inhibited the seed germination,shoot length, root length and drymatter production of pearmillet, cowpea, sesamum and cucumber.

The reduction in the seedling growth and biomass production may be due to imbalance in water uptake or osmotic balance of the tissues for germination and growth by the allelochemical toxicity of the extracts (Blum et al., 1999).The inhibitory effects may be due to the presence of higher amounts of growth inhibitory substances in the tuber extracts that were released during extraction. The differential degree of inhibitory (5, $10,15,20$ and $25 \%$ ) effect on the growth of rice cultivars may be due to the presence of various allelochemicals at different levelin both the weed extracts. Previous phytochemical studies on $C$. rotundus revealed the presence of alkaloids, flavonoids, tannins, starch, glycosides and furochromones, and many novel sesquiterpenoids (Raut et al., 2006; EL-Habashy et al., 1989; Kapadia et al., 1967; Jeong et al., 2000; Sayed et al., 2007; Xuet al., 2008). The herb C.dactylon contains beta sitosterol, beta-carotene, vitamin C, palmitic acid, andtriterpenoids. Alkaloids like ergonovine, ergonovivine, others include ferulic acid, syringic acid, vanillin acid,p-coumaric acid (Ravindra, 2003). 
Table 1. Germination Percentage of rice cultivars exposed to aqueous extracts of Cyperus rotundus and Cynodon dactylon.

\begin{tabular}{|c|c|c|c|c|c|c|}
\hline \multirow{2}{*}{$\begin{array}{c}\text { Extract Concentrations } \\
(\%)\end{array}$} & \multicolumn{3}{|c|}{ C.rotundus } & \multicolumn{3}{|c|}{ C.dactylon } \\
\hline & ADT-36 & BPT & IR-20 & ADT-36 & BPT & IR-20 \\
\hline Control & 98.0 & 96.0 & 98.0 & 98.0 & 96.0 & 98.0 \\
\hline & - & - & - & - & - & - \\
\hline $5 \%$ & $\begin{array}{c}85.0 \\
(-13.3)\end{array}$ & $\begin{array}{c}86.8 \\
(-9.6)\end{array}$ & $\begin{array}{c}91.5 \\
(-6.6)\end{array}$ & $\begin{array}{c}89.6 \\
(-8.6)\end{array}$ & $\begin{array}{c}89.0 \\
(-7.3)\end{array}$ & $\begin{array}{c}94.2 \\
(-3.9)\end{array}$ \\
\hline $10 \%$ & 72.5 & 74.6 & 82.6 & 80.2 & 83.5 & 85.6 \\
\hline 1070 & $(-26.0)$ & $(-22.3)$ & $(-15.7)$ & $(-18.2)$ & $(-13.0)$ & $(-12.6)$ \\
\hline $15 \%$ & $\begin{array}{c}60.8 \\
(-38.0 .)\end{array}$ & $\begin{array}{c}65.0 \\
(-32.3)\end{array}$ & $\begin{array}{c}71.5 \\
(-27.0)\end{array}$ & $\begin{array}{c}65.3 \\
(-33.4)\end{array}$ & $\begin{array}{c}68.5 \\
(-28.5)\end{array}$ & $\begin{array}{c}76.2 \\
(-22.2)\end{array}$ \\
\hline $20 \%$ & $\begin{array}{c}56.0 \\
(-42.8)\end{array}$ & $\begin{array}{c}60.5 \\
(-37.0)\end{array}$ & $\begin{array}{c}65.3 \\
(-33.3)\end{array}$ & $\begin{array}{c}59.2 \\
(-40.0)\end{array}$ & $\begin{array}{c}62.5 \\
(-34.8)\end{array}$ & $\begin{array}{c}71.5 \\
(27.04)\end{array}$ \\
\hline $25 \%$ & $\begin{array}{c}44.0 \\
(-55.1)\end{array}$ & $\begin{array}{c}47.3 \\
(-50.7)\end{array}$ & $\begin{array}{c}59.2 \\
(-40.0)\end{array}$ & $\begin{array}{c}50.5 \\
(-48.4)\end{array}$ & $\begin{array}{c}58.6 \\
(-39.0)\end{array}$ & $\begin{array}{c}63.6 \\
(-35.1)\end{array}$ \\
\hline
\end{tabular}

*Value in parenthesis indicate the percentage of decrease $(-)$ over control

Table 2. Root length and shoot length (cm/plant) of rice cultivars exposed to aqueous extracts of Cyperus rotundus and Cynodon dactylon.

\begin{tabular}{|c|c|c|c|c|c|c|c|c|c|c|c|c|}
\hline \multirow{3}{*}{$\begin{array}{c}\text { Extract } \\
\text { Concentrations } \\
(\%) \\
\end{array}$} & \multicolumn{6}{|c|}{ C. rotundus } & \multicolumn{6}{|c|}{ C. dactylon } \\
\hline & \multicolumn{3}{|c|}{ Root length } & \multicolumn{3}{|c|}{ Shoot length } & \multicolumn{3}{|c|}{ Root length } & \multicolumn{3}{|c|}{ Shoot length } \\
\hline & ADT-36 & BPT & IR-20 & ADT-36 & BPT & IR-20 & ADT-36 & BPT & IR-20 & ADT-36 & BPT & IR-20 \\
\hline Control & 3.3 & 4.0 & 4.3 & 12.5 & 16.0 & 19.8 & 3.3 & 4.0 & 4.3 & 12.5 & 16.0 & 19.8 \\
\hline $5 \%$ & $\begin{array}{c}2.85 \\
(-13.6)\end{array}$ & $\begin{array}{c}3.49 \\
(- \\
12.7)\end{array}$ & $\begin{array}{c}3.87 \\
(- \\
10.0)\end{array}$ & $\begin{array}{r}10.86 \\
(-13.1)\end{array}$ & $\begin{array}{c}14.43 \\
(- \\
10.0)\end{array}$ & $\begin{array}{l}19.38 \\
(-2.2)\end{array}$ & $\begin{array}{c}3.04 \\
(-7.9)\end{array}$ & $\begin{array}{c}3.68 \\
(-8.0)\end{array}$ & $\begin{array}{c}4.1 \\
(-4.6)\end{array}$ & $\begin{array}{l}11.44 \\
(-8.4)\end{array}$ & $\begin{array}{l}14.96 \\
(-6.5)\end{array}$ & $\begin{array}{l}19.62 \\
(-1.0)\end{array}$ \\
\hline $10 \%$ & $\begin{array}{c}2.59 \\
(-21.5)\end{array}$ & $\begin{array}{c}3.25 \\
(- \\
18.7)\end{array}$ & $\begin{array}{c}3.76 \\
(- \\
12.5)\end{array}$ & $\begin{array}{c}10.00 \\
(-20.0)\end{array}$ & $\begin{array}{c}13.47 \\
(- \\
15.8)\end{array}$ & $\begin{array}{l}18.35 \\
(-7.3)\end{array}$ & $\begin{array}{c}2.72 \\
(-17.5)\end{array}$ & $\begin{array}{c}3.46 \\
(- \\
13.5)\end{array}$ & $\begin{array}{c}3.89 \\
(-9.5)\end{array}$ & $\begin{array}{r}10.39 \\
(-17.2)\end{array}$ & $\begin{array}{c}14.19 \\
(- \\
11.3)\end{array}$ & $\begin{array}{l}18.74 \\
(-5.3)\end{array}$ \\
\hline $15 \%$ & $\begin{array}{c}2.19 \\
(-33.6)\end{array}$ & $\begin{array}{c}2.72 \\
(- \\
32.0)\end{array}$ & $\begin{array}{c}3.21 \\
(- \\
25.3)\end{array}$ & $\begin{array}{c}8.37 \\
(-33.0)\end{array}$ & $\begin{array}{l}11.55 \\
(- \\
28.1)\end{array}$ & $\begin{array}{c}15.86 \\
(- \\
20.0)\end{array}$ & $\begin{array}{c}2.29 \\
(-30.6)\end{array}$ & $\begin{array}{c}2.96 \\
(- \\
26.0)\end{array}$ & $\begin{array}{c}3.44 \\
(-20.0)\end{array}$ & $\begin{array}{c}8.93 \\
(-28.6)\end{array}$ & $\begin{array}{c}12.41 \\
(- \\
22.4)\end{array}$ & $\begin{array}{c}17.12 \\
(- \\
13.5)\end{array}$ \\
\hline & 1.78 & 2.25 & $\begin{array}{c}2.75 \\
6-\end{array}$ & 7.02 & $\begin{array}{c}9.42 \\
-\end{array}$ & 14.22 & 2.02 & $\begin{array}{c}2.52 \\
(-\end{array}$ & 3.33 & 7.65 & 11.18 & 16.26 \\
\hline $20 \%$ & $(-46.1)$ & $\begin{array}{c}(- \\
43.7)\end{array}$ & $36.0)$ & $(-44.0)$ & 41.1) & $28.1)$ & $(-38.8)$ & $37.0)$ & $(-23.2)$ & $(-37.5)$ & $30.1)$ & $17.8)$ \\
\hline $25 \%$ & $\begin{array}{c}1.48 \\
(-55.1)\end{array}$ & $\begin{array}{c}1.87 \\
(- \\
53.2)\end{array}$ & $\begin{array}{c}2.39 \\
(- \\
44.4)\end{array}$ & $\begin{array}{c}6.27 \\
(-49.8)\end{array}$ & $\begin{array}{c}8.73 \\
(- \\
45.4)\end{array}$ & $\begin{array}{c}12.01 \\
(- \\
40.0) \\
\end{array}$ & $\begin{array}{c}1.66 \\
(-50.0)\end{array}$ & $\begin{array}{c}2.32 \\
(- \\
42.0)\end{array}$ & $\begin{array}{c}2.72 \\
(-36.7)\end{array}$ & $\begin{array}{c}6.63 \\
(-47.0)\end{array}$ & $\begin{array}{c}10.33 \\
(- \\
35.3)\end{array}$ & $\begin{array}{c}15.69 \\
(- \\
20.8)\end{array}$ \\
\hline
\end{tabular}

*Value in parenthesis indicate the percentage of decrease (-) over control 
Table 3. Dry weight (g/plant) and Total Chl. Content (mg/g.fr.wt.) of rice cultivars exposed to aqueous extracts of Cyperus rotundusand Cynodon dactylon.

\begin{tabular}{|c|c|c|c|c|c|c|c|c|c|c|c|c|}
\hline \multirow{3}{*}{$\begin{array}{c}\text { Extract Concentrations } \\
(\%)\end{array}$} & \multicolumn{6}{|c|}{ C.rotundus } & \multicolumn{6}{|c|}{ C. dactylon } \\
\hline & \multicolumn{3}{|c|}{ Dry weight } & \multicolumn{3}{|c|}{ Total Chl. } & \multicolumn{3}{|c|}{ Dry weight } & \multicolumn{3}{|c|}{ Total Chl. } \\
\hline & ADT-36 & BPT & IR-20 & ADT-36 & BPT & IR-20 & ADT-36 & BPT & IR-20 & ADT-36 & BPT & IR-20 \\
\hline Control & 0.55 & 0.72 & 0.93 & 0.963 & 0.989 & 1.152 & 0.55 & 0.72 & 0.93 & 0.963 & 0.989 & 1.152 \\
\hline $5 \%$ & $\begin{array}{c}0.41 \\
(-25.4)\end{array}$ & $\begin{array}{c}0.67 \\
(-7.0)\end{array}$ & $\begin{array}{c}0.87 \\
(-6.4)\end{array}$ & $\begin{array}{c}0.845 \\
(-12.6)\end{array}$ & $\begin{array}{c}0.888 \\
(-10.2)\end{array}$ & $\begin{array}{r}0.972 \\
(-15.6)\end{array}$ & $\begin{array}{c}0.43 \\
(-21.8)\end{array}$ & $\begin{array}{c}0.69 \\
(-8.3)\end{array}$ & $\begin{array}{c}0.91 \\
(-2.2)\end{array}$ & $\begin{array}{r}0.859 \\
(-10.7)\end{array}$ & $\begin{array}{l}0.913 \\
(-5.2)\end{array}$ & $\begin{array}{c}0.968 \\
(-16.0)\end{array}$ \\
\hline $10 \%$ & $\begin{array}{c}0.38 \\
(-31.0)\end{array}$ & $\begin{array}{c}0.58 \\
(-19.4)\end{array}$ & $\begin{array}{c}0.75 \\
(-19.3)\end{array}$ & $\begin{array}{c}0.768 \\
(-20.2)\end{array}$ & $\begin{array}{c}0.818 \\
(-17.3)\end{array}$ & $\begin{array}{r}0.944 \\
(-18.1)\end{array}$ & $\begin{array}{c}0.38 \\
(-30.0)\end{array}$ & $\begin{array}{c}0.62 \\
(-13.8)\end{array}$ & $\begin{array}{c}0.82 \\
(-11.5)\end{array}$ & $\begin{array}{r}0.832 \\
(-13.6)\end{array}$ & $\begin{array}{r}0.868 \\
(-13.4)\end{array}$ & $\begin{array}{c}0.957 \\
(-17.0)\end{array}$ \\
\hline $15 \%$ & $\begin{array}{l}0.26 \\
(-52.7)\end{array}$ & $\begin{array}{c}0.54 \\
(-25.0)\end{array}$ & $\begin{array}{c}0.74 \\
(-20.4)\end{array}$ & $\begin{array}{c}0.619 \\
(-35.7)\end{array}$ & $\begin{array}{c}0.722 \\
(-27.0)\end{array}$ & $\begin{array}{r}0.810 \\
(-30.0)\end{array}$ & $\begin{array}{c}0.29 \\
(-47.2)\end{array}$ & $\begin{array}{c}0.55 \\
(-23.6)\end{array}$ & $\begin{array}{c}0.79 \\
(-15.5)\end{array}$ & $\begin{array}{c}0.787 \\
(-18.3)\end{array}$ & $\begin{array}{r}0.765 \\
(-22.6)\end{array}$ & $\begin{array}{c}0.865 \\
(-25.0)\end{array}$ \\
\hline $20 \%$ & $\begin{array}{c}0.21 \\
(-61.8)\end{array}$ & $\begin{array}{c}0.42 \\
(-41.7)\end{array}$ & $\begin{array}{c}0.60 \\
(-35.5)\end{array}$ & $\begin{array}{c}0.544 \\
(-43.5)\end{array}$ & $\begin{array}{c}0.583 \\
(-41.0)\end{array}$ & $\begin{array}{r}0.763 \\
(-33.7)\end{array}$ & $\begin{array}{c}0.22 \\
(-60.0)\end{array}$ & $\begin{array}{c}0.49 \\
(-32.0)\end{array}$ & $\begin{array}{c}0.65 \\
(-30.0)\end{array}$ & $\begin{array}{r}0.586 \\
(-40.2)\end{array}$ & $\begin{array}{r}0.655 \\
(-36.8)\end{array}$ & $\begin{array}{r}0.785 \\
(32.0)\end{array}$ \\
\hline $25 \%$ & $\begin{array}{c}0.18 \\
(-67.3)\end{array}$ & $\begin{array}{c}0.38 \\
(-47.2)\end{array}$ & $\begin{array}{c}0.55 \\
(-40.8)\end{array}$ & $\begin{array}{c}0.452 \\
(-54.3)\end{array}$ & $\begin{array}{c}0.519 \\
(-47.5)\end{array}$ & $\begin{array}{c}0.611 \\
(-29.0)\end{array}$ & $\begin{array}{c}0.20 \\
(-63.6)\end{array}$ & $\begin{array}{c}0.40 \\
(-44.4)\end{array}$ & $\begin{array}{c}0.62 \\
(-33.3)\end{array}$ & $\begin{array}{r}0.523 \\
(-45.7)\end{array}$ & $\begin{array}{c}0.586 \\
(-40.7)\end{array}$ & $\begin{array}{c}0.689 \\
(-40.2)\end{array}$ \\
\hline
\end{tabular}

*Value in parenthesis indicate the percentage of decrease (-) over control.

Akobundu (1987), listed factors such as soil temperature, soil moisture regime, alternate wetting and drying of soil, soil nitrate level among others as those that affect seed germination. These results are supported by the findings of Oke (1988) that siamweed extract inhibited the germination of seeds of cowpea, soybean and tridax. JaiKnoxet al.,(2010) reported that Cassia occidentalis, Rumex dentatus, Calotropis procera and Withaniasomnifera inhibited germination and growth of Parthenium hysterophorus. The presence of inhibitory chemicals in higher concentrations of the extract might be the reason for differential behaviour of the extracts and causing maximum reduction in growth of the seedlings. Phytotoxicity of allelochemicals present in the weed extracts might be caused synergistic activity on the germination and growth of rice seedlings rather than single chemical. The statistically observed significances are evident for the inhibitory effects of C.ortundusandC.dactylon on the growth of rice cultivars.

\section{REFERENCES}

Akobundu, I.O. (1987). Weed Science in the tropics: Principles and practices.John Whiley and Sons; $522 \mathrm{pp}$.

Alsaadawi I.S. and N.M.M. Salih (2009). Allelopathic potential of Cyperus rotundus L. Interference with crops. Allelopathy J. 23(1).

Bhatt, B.P. and D.S. Chauhan, (2000). Allelopathic effects of Quercus spp.on crops of Garhawal Himalaya. Allelopathy J. 7(2): 265-272.

Blum, U., S.R. Shafer and M.E. Lehman, (1999). Evidence of inhibitory allelopathic interactions involving phenolic acids in field soils: concepts vs. an experimental model. Crit. Rev. Plant Sci. 18:673-693.

Channappagoudar, B.B., B.R. Jalager and N.R. Biradar, (2005). Allelopathic effect of aqueous extracts of weed species on germination and seedling growth of some crops. Karnataka J.Agriculture 18:916-920. 
Drost, D.A. and J.D. Doll, (1980). Allelopathic effect of yellow nutsedge (Cyperus esculentus) on corn (Zea mays) and soyabeans (Glycine max), Weed Science, Weed Science Society of America 28(2).

EL-Habashy, I., R.M.A. Mansour, M.A. Zahran, M.M. EL-Hadid and N.A. Saleh, (1989). Leaf flavonoids of Cyperus species in Egypt. Bio. Syst. Ecol. 17:191-195.

Fisher, R.F. (1980). In:"Plant disease"- Anadvance Treatise (F.G. Horrfall and E.B. Cawling, Eds.,). Academic press, New York. pp: 313.

Gordon-Gray, K.D. (1995). Cyperaceae in Natal, National Botanical Institute: Pretoria, South Africa. pp. 45-76.

Jai Knox, DishaJaggi and M.S. Paul, (2010). Allelopathic Effect of Selected Weeds on Biochemical Activity of Parthenium hysterophorus. Curr. Res. J. Biol. Sci., 2(4): 238240.

Jeong, S.J. Miyamoto, T., Inagaki, M., Kim, Y.C., Higuchi, R. Rotundines A-C, three novel sesquiterpene alkaloids from Cyperus rotundus. J. Nat. Prod. 2000, 63, 673-675.

Jeyasrinivas, A. Senthil, C. Chinnusamy and G. Prabukumar, (2006). Allelopathic influence of weed species on the established of field crops. J. Allelopathy 17(1): 123-128.

Kapadia, V.H., V.G. Naik M.S. Wadia and S. Devi, (1967). Sesquiterpenoids from Essential oil of Cyperus rotundus. Tetrahedron Lett. 4661p.

Muller, C.H., (1969). Allelopathy as a factor in ecological process. Vegetation, 18: 348-357.

Nadkarni, A.K., (2000). Indian Meteria Medica, Vol 1, Mumbai, India Popular Prakashan p. 425.

Oke, A.E. (1988). The allelopathic potential ofChromolaenaodorataon seed germination and seedling growth of vigina unguiculata var. K59 and Zea mays var DMR-SRW and germination of C. odorata and Tridaxprocumbensweed seeds. B. Agric. Tech. (Crop production) Project Report; The Federal University of Tech., Akure, Nigeria. $14 \mathrm{p}$.
Padhy, B., P.K. Patinaik and A.K. Tripathy, (2000). Allelopathic potential of Eucalyptus leaf litter leachates on germination and seedling growth of finger millet. Allelopathy J. 7: 69-78.

Pooley, E. (1998). A Field Guide to Wild Flowers in KwaZulu-Natal and Eastern Region. Natal Flora Publications Trust: Durban, South Africa, p.562.

Rao, V.S. (1983). Principles of Weed Science.Oxford and IBH Publishing Co.NewDelhi, India.

Raut, N.A. and N.J. Gaikwad, (2006). Antidiabetic activity of hydro-ethanolic extract of Cyperus rotundusin alloxan induced diabetes in rats. Fitoterapia, 77: 585-588.

Ravindra, S. (2003). Medicinal plants of India an Encyclopedia, Daya Publishing House, New Delhi, 79-80.

Sayed, H.M., M.H. Mohamed, S.F. Farag, G.A. Mohamed, P.A. Proksch, (2007). A new steroid glycoside and furochromones from Cyperus rotundus L. Nat. Prod. Res. 21: 343-350.

Tripathi, S., A. Tripathi, D.C. Kori and S. Tiwari, (1998). Effect of tree leaves aqueous extracts on germination and seedlings growth of soybean. Allelopathy J. 5(1): 75-82.

Vaidyaratnam, P.S.V. (2003). Arya Vaidya Sala, Kottakkal, Vol II, Chennai: Orient Longham. 289 p.

Verma, R., P.B. Rao and Y.S. Rawat, (2002). Allelopathic effects of certain weed extracts on seed germination of ten varieties of the genus Brassica. Nat. Biosphere, 7(1-2): 26-31.

Whittaker, R.H., (1999). In: Chemical Ecology (E. Sondheimer and J. B. Simeone, eds.) pp. 43-70. Academic Press, New York.

Whittaker, R.H. and P.P. Feeny, (1971). Allelochemics: Chemical interactions among species, Science 171:757-770.

Xu, Y. H. Zhang, C. Yu, Y. Lu, Y. Chang, Z. Zou, (2008). Norcyperone, a Novel Skeleton Norsesquiterpene from Cyperus rotundus $\mathrm{L}$. Molecules 13: 2474-2481. 